\title{
CHEBYSHEV'S DIFFERENTIAL EQUATION AND ITS HYERS-ULAM STABILITY
}

\author{
SoOn-Mo Jung And Byungbae Kim
}

Abstract. We solve the inhomogeneous Chebyshev's differential equation and apply this result to obtain a partial solution to the Hyers-Ulam stability problem for the Chebyshev's differential equation.

Mathematics subject classification (2000): Primary 34A05, 39B82; Secondary 26D10, 34A40.

Keywords and phrases: Chebyshev's differential equation, Chebyshev function, Hyers-Ulam stability, approximation.

\section{REFERENCES}

[1] C. Alsina AND R. GER, On some inequalities and stability results related to the exponential function, J. Inequal. Appl. 2 (1998), 373-380.

[2] S. CZERWIK, Functional Equations and Inequalities in Several Variables, World Scientific, River Edge, NJ, 2002.

[3] D. H. HYERS, On the stability of the linear functional equation, Proc. Nat. Acad. Sci. USA 27 (1941), $222-224$.

[4] D. H. Hyers, G. Is AC AND Th. M. RAssias, Stability of Functional Equations in Several Variables, Birkhäuser, Boston, 1998.

[5] D. H. Hyers AND TH. M. Rassias, Approximate homomorphisms, Aequationes Math. 44 (1992), $125-153$.

[6] S.-M. Jung, Hyers-Ulam-Rassias Stability of Functional Equations in Mathematical Analysis, Hadronic Press, Palm Harbor, 2001.

[7] S.-M. JUnG, Hyers-Ulam stability of linear differential equations of first order, Appl. Math. Lett. 17 (2004), 1135-1140.

[8] S.-M. Jung, Hyers-Ulam stability of linear differential equations of first order, II, Appl. Math. Lett. 19 (2006), 854-858.

[9] S.-M. JUnG, Hyers-Ulam stability of linear differential equations of first order, III, J. Math. Anal. Appl. 311 (2005), 139-146.

[10] S.-M. JUNG, Hyers-Ulam stability of a system of first order linear differential equations with constant coefficients, J. Math. Anal. Appl. 320 (2006), 549-561.

[11] S.-M. Jung, Legendre's differential equation and its Hyers-Ulam stability, Abst. Appl. Anal. 2007 (2007), Article ID 56419, 14 pages, doi: 10.1155/2007/56419.

[12] S.-M. Jung, Approximation of analytic functions by Airy functions, Integral Transforms and Special Functions 19 (2008), no. 12, 885-891.

[13] B. Kim AND S.-M. JUNG, Bessel's differential equation and its Hyers-Ulam stability, J. Inequal. Appl. 2007 (2007), Article ID 21640, 8 pages, doi: 10.1155/2007/21640.

[14] T. MiURA, On the Hyers-Ulam stability of a differentiable map, Sci. Math. Japon. 55 (2002), 17-24.

[15] T. MiURA, S.-M. JUng AND S.-E. TAKAHASI, Hyers-Ulam-Rassias stability of the Banach space valued differential equations $y^{\prime}=\lambda y$, J. Korean Math. Soc. 41 (2004), 995-1005.

[16] T. MiURA, S. MiYajima AND S.-E. TAKAhASi, Hyers-Ulam stability of linear differential operator with constant coefficients, Math. Nachrichten 258 (2003), 90-96.

[17] T. MiURA, S. MiYaJima And S.-E. TAKAhasi, A characterization of Hyers-Ulam stability of first order linear differential operators, J. Math. Anal. Appl. 286 (2003), 136-146. 
[18] Th. M. Rassias, On the stability of the linear mapping in Banach spaces, Proc. Amer. Math. Soc. 72 (1978), 297-300.

[19] S.-E. Takahasi, T. Miura And S. MiYajima, On the Hyers-Ulam stability of the Banach spacevalued differential equation $y^{\prime}=\lambda y$, Bull. Korean Math. Soc. 39 (2002), 309-315.

[20] S. M. Ulam, Problems in Modern Mathematics, Wiley, New York, 1964. 